\title{
Spinal Tumor Surgery- Our Experiences of 35 Cases in a Peripheral Hospital in Bangladesh
}

\author{
Md. Mohsin Ali Farazi"1, Md. Ibrahim Khalil ${ }^{2}$, Shyamol Pal ${ }^{3}$, M. Belal Uddin ${ }^{4}$, Moutusi Sorowar ${ }^{5}$
}

\begin{abstract}
Introduction: Surgical outcome of spinal tumour varies depending on a number of factors such as: site of the tumour, compression within the spinal canal, the histological characteristics of the tumour, the neurological progression and initial response to corticosteroid therapy, patient's age, comorbidity, tumour extension, involvement of neighboring structures and organs etc. Materials \& Methods: The 35 patients with spinal tumour underwent surgery by our team in 10 years (January 2009 - December 2018) were reviewed retrospectively. Results: Analysis of the surgical outcome of our spinal tumour patients was done on different variables like age, sex, presenting symptoms, neuroimaging, comorbidities etc. The aim of surgery was decompression of the spinal cord, total removal of the tumour when possible and spinal stabilization when needed. Out of our 35 patients with spinal tumour, extradural tumour comprises 8, intradural extramedullary tumour 25 and intramedullary tumour 2. Conclusion: The aim of this study is to analyze the data to made conclusion for more effective strategy as per site, size, type, resectibility and histological variety to establish and effective treatment protocol and prevention of per-operative and post-operative complications. Intradural extramedullary tumour can be radically resected with no mortality and minimal peri-operative morbidity. But resection of intramedullary spinal tumour is difficult, hazardous and usually incomplete, so needs much more skilled and meticulous surgical hands.
\end{abstract}

Keywords: Spinal tumours, Spinal cord compression, Surgical outcome, Intramedullay, Extramedullary.

Number of Tables: 08; Number of References: 30; Number of Correspondence: 03.

*1. Corresponding Author:

Dr. Md. Mohsin Ali Farazi

Assistant Professor

Department of Neurosurgery

Shaheed Sheikh Abu Naser Specialized Hospital, Khulna, Bangladesh.

E-mail-mohsinfarazi@yahoo.com

Mobile: 88001711964550

2. Dr. Md. Ibrahim Khalil

Junior Consultant

Department of Neurosurgery

Shaheed Sheikh Abu Naser Specialized Hospital, Khulna, Bangladesh.

3. Dr. Shyamol Pal

Assistant Registrar

Department of Neurosurgery

Shaheed Sheikh Abu Naser Specialized Hospital, Khulna, Bangladesh.

4. Dr. M. Belal Uddin

Assistant Professor

Department of Anesthesiology

Shaheed Sheikh Abu Naser Specialized Hospital, Khulna, Bangladesh.

5. Dr. Moutusi Sorowar

Assistant Professor

Department of Anesthesiology

Khulna Medical College, Khulna, Bangladesh.

\section{Introduction:}

Surgical outcome of spinal tumours varies depending on a number of factors such as: site of tumour, compression within the spinal canal, the histological characteristics of tumour, the neurological progression and initial response to corticosteroid therapy, patient's age, comorbidity, tumour extension, involvement of neighboring structures and organs etc. Treatment of spine and spinal cord tumour is complex and a multidisciplinary approach is required ${ }^{1}$. Treatment options are surgery, radiation therapy and chemotherapy ${ }^{2}$. This study was conducted to analyze factors with impact on the functional outcome in a series of 35 surgically treated patients with spinal tumour and to point out the characteristics of the different histological entities. The signs and symptoms of intradural extramedullary tumour are not specific to tumours and are similar to those caused by any spinal disorder that produces symptoms of spinal cord or nerve root compression. Because of the slow growth of these tumours, symptoms may be subtle and progress slowly overtime before diagnosis ${ }^{3}$. The benign nature of ordinary spinal schwannomas is well documented ${ }^{4-7}$. Total surgical removal can usually be achieved and shortterm outcome is favorable in those who are not too severely crippled before operation ${ }^{5,7}$.

Intradural-extramedullary (ID-EM) tumours are the most commonly observed intradural spinal tumours, comprising over $60 \%$ of tumours found within the spinal canal ${ }^{8}$. While consisting of a heterogeneous group of pathological entities, the vast majority of these lesions are one of three types: meningiomas, schwannoma or neurofibroma 9 . Fortunately, the more common tumours are typically benign and surgical excision represents the possibility of a curative result ${ }^{10}$. Surgical outcomes have generally been quite 
positive, with multiple studies quoting gross total resection rates approaching $100 \%$ with minimal morbidity and mortality regardless of histologic subtype ${ }^{11,12}$.

\section{Materials \& Methods:}

A descriptive cross sectional study was conducted from January 2009 to December 2018 where 35 patients with spinal tumour underwent surgery by our team, among those 19 were male and 16 were female in were reviewed retrospectively.

Results:

Table-I: (Distribution of the patients: (According to the site).

\begin{tabular}{l|l}
\hline \multicolumn{1}{c|}{ Site } & No of Patients \\
\hline Extradural (ED) & $08(22.85 \%)$ \\
Intradural extramedullary (IDEM) & $25(71.42 \%)$ \\
Intramedullary (IM) & $02(5.71 \%)$ \\
\hline
\end{tabular}

Table-II: (Distribution of the patient according to age).

\begin{tabular}{l|l}
\hline Age & No of Patients \\
\hline$<20$ & $04(11.43 \%)$ \\
$21-40$ & $17(48.57 \%)$ \\
$41-60$ & $10(28.57 \%)$ \\
$61-80$ & $04(11.43 \%)$ \\
\hline
\end{tabular}

Table-III: (Distribution of the patient according to sex).

\begin{tabular}{l|l}
\hline Sex & No of Patients \\
\hline Male & $19(54.28 \%)$ \\
Female & $16(45.72 \%)$ \\
\hline
\end{tabular}

Table -IV: (Distribution of the patient according to the region in the spinal column).

\begin{tabular}{c|l}
\hline Region in the spinal column & No of Patients \\
\hline Cervical & $09(25.71 \%)$ \\
Dorsal & $18(51.43 \%)$ \\
Lumbar & $07(20 \%)$ \\
Sacral & $02(5.71 \%)$ \\
Conus & $01(2.85 \%)$ \\
\hline
\end{tabular}

Table-V: (Distribution of the patient according to the sypmtoms).

\begin{tabular}{c|l}
\hline Presenting symptoms & No of Patients \\
\hline Pain & $35(100 \%)$ \\
Numbness & $30(94.28 \%)$ \\
Paraparesis & $18(51.43 \%)$ \\
Paraplegia & $05(14.28 \%)$ \\
Quadriparesis & $09(25.71 \%)$ \\
Cauda equine syndrome & $02(5.71 \%)$ \\
\hline
\end{tabular}

\section{Neuro-imaging \\ Plain X-ray 35 (100\%) \\ MRI 35 (100\%)}

The aim of surgery was decompression of the spinal cord, total removal of the tumour when possible and spinal stabilization when needed. Most of the cases were done by laminectomy or laminoplasty.
Many factors have influenced the outcome of surgical treatment. The most important are the histological characteristics of tumour, spinal segment affected and the degree of decompression.

Table-VI:

\begin{tabular}{l|l}
\hline \multicolumn{1}{c|}{ Histological characters } & No of Patients \\
\hline Schwannoma & $14(40 \%)$ \\
Meningioma & $7(20 \%)$ \\
Ependymoma & $2(5.71 \%)$ \\
Chordoma & $2(5.71 \%)$ \\
Metastatic (adenocarcinoma) & $2(5.71 \%)$ \\
Ganglioglioma & $1(2.86 \%)$ \\
Hemangioma & $1(2.86 \%)$ \\
Arachnoid cyst & $1(2.86 \%)$ \\
Clear cell tumor & $1(2.86 \%)$ \\
Cavernoma & $1(2.86 \%)$ \\
Plasma cell tumor & $1(2.86 \%)$ \\
Neurofibroma & $2(5.71 \%)$ \\
\hline
\end{tabular}

Satisfactory postoperative outcome corresponds with the degree of decompression (e.g. total removal of meningioma or neurofibroma leads to full recovery), but decompression in cases of primary intramedullary tumours and metastases were not always satisfactory.

\section{Extent of tumour resection:}

Table-A

Surgical resection

\begin{tabular}{l|l}
\hline \multicolumn{1}{c|}{ Trait } & Number (\%) \\
\hline Gross total & $22(62.86 \%)$ \\
Near total & $08(22.86 \%)$ \\
Subtotal & $03(8.57 \%)$ \\
Biopsy only & $02(5.71 \%)$ \\
\hline
\end{tabular}

\section{Table-B}

Clinical improvement

\begin{tabular}{l|l}
\hline \multicolumn{1}{c|}{ Trait } & Number (\%) \\
\hline Immediate improvement & $07(20 \%)$ \\
Improvement at discharge (7 days) & $12(34.28 \%)$ \\
Improvement at first month follow-up & $10(28.57 \%)$ \\
No improvement & $02(5.71 \%)$ \\
Deterioration & $03(8.57 \%)$ \\
Death & $01(2.85 \%)$ \\
\hline
\end{tabular}

The most frequent difficulties encountered during surgery was the per operative bleeding, anesthetic hazard in previously pulmonary compromised patient etc.
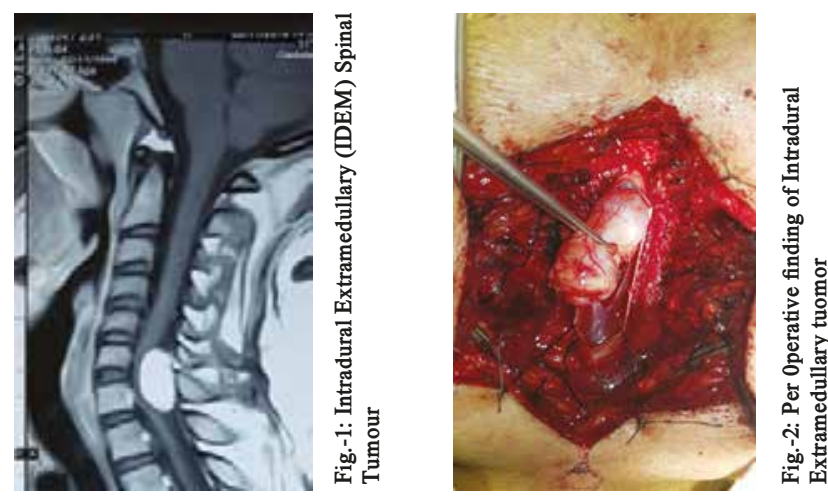
Postoperative complications includes CSF leakage 2 (5.71\%), Wound infection 1 (2.85\%), Deformity $1(2.85 \%)$, Pneumonia 1(2.85\%).

\section{Discussion:}

The optimal surgical approach provides maximal exposure with the least manipulation of the neural elements. For most intradural extramedullary tumours, resection can be accomplished with a midline approach. As a general rule, lesions dorsal to the spinal cord can be reached easily using a dorsal midline approach, whereas lesions ventral and lateral to the spinal cord may require resection to provide the best trajectory to the tumour ${ }^{13}$. In our study, the most of the patients were male19 $(54.28 \%)$ and belong to the age group of 21-40 years 17 (48.57\%). Similar scenario regarding age and sex was reported in Islam MR et $\mathrm{al}^{2}$. Our study presented with variable types of symptoms, among which pain contributes as $100 \%$ and numbness as $94.28 \%$. In our study 18 cases were at dorsal spine involvement which was highest in location (51.42\%). Regarding nature of tumour the most frequent cases were Schwannoma 14 (40\%) followed by meningioma $7(20 \%)$. The extent of tumour resection and decompression correlates directly with a good outcome. The extent of excision either incomplete or biopsy was found to positively correlate with postoperative improvement. In our study 22 cases $(62.86 \%)$ were underwent operation with gross total removal of tumour, 08 cases $(22.86 \%)$ were underwent operation with near-total removal of tumour, 03 cases $(8.57 \%)$ were underwent operation with sub-total resection of tumour and in rest 02 cases $(5.71 \%)$ only biopsy were taken. In our study 12 patients $(34.28 \%)$ were discharged at 7 th post-operative day with significant improvement. In 07 patients $(20 \%)$ of our study, immediate postoperative improvement were observed. There was no post-operative improvement in 2 cases (5.71\%), deterioration in 03 cases $(8.57 \%)$ and 01 patients died $(2.85 \%)$ due to severe cardiac complications. Post-operative complications varies from $10-50 \%{ }^{14-29}$. In our study there were different type of post-operative complication like CSF leakage in 2 cases $(5.71 \%)$, wound infection in 1 case $(2.85 \%)$, deformity in 1 case $(2.85 \%)$ and pneumonia in 1 case $(2.85 \%)$.

\section{Conclusion:}

To achieve good surgical outcome, reduce postoperative mortality and peri-operative morbidity in case of spinal tumours, each neurosurgeon has to perform meticulous anatomical dissection mandatorily with modern sophisticated instruments like operating microscope. Besides this, early mobilization \& rehabilitation are essential for good clinical outcome ${ }^{30}$. CSF leak and pseudomeningocele formation may be prevented with meticulous dural closure, fat grafting for obliteration of the dead space and 48 hours postoperative bed rest. Patients tend to completely recover their preoperative neurologic deficits even in the case of longstanding preoperative neurological deficit.
Conflict of Interest: None.

\section{Acknowledgement:}

Study was performed in the Department of Neurosurgery, Shaheed Sheikh Abu Naser Specialized Hospital, Khulna, Bangladesh.

All the patients were examined and reviewed separately with verbal and written consent.

\section{References:}

1. T. Avramov, G. Kyuchukov, I. Kiryakov, N. Obreshkov, D. Handjiev, R. Nedelko. Clinic of Neurosurgery and Neurology, St. Anna Hospital, Varna Department of Neurosurgery, Eye diseasesand ENT, Medical University "Prof. P. Stoyanov", Varna, Bulgaria: Results of Spinal Tumours Surgery. Journal of IMAB - Annual Proceeding (Scientific Papers). 2009; book 1.

2. Islam MR, Siddique MSA, Ahmed M, Khan AS, Afreen S, Das S, et al. Spinal Tumour Surgery 6 Month Follow up in 34 Cases: Bang. J Neurosurgery. 2014; 3(2): 46-50.

3. Cavalcanti DD, Martirosyan NL, Verma K. Surgical management and outcome of schwannomas in the craniocervical region. J Neurosurg. 2011;114:1257-1267.

https://doi.org/10.3171/2010.5.JNS0966

PMid:20617880

4. Hori T, Takakura K, Sano K. Spinal neurinomas-clinical analysis of 45 surgical cases. Neurol Med Chir. 1984; 24:471-477.

https://doi.org/10.2176/nmc. 24.471

PMid:6208497

5. Iraci G, Peserico L, Salar G. Intraspinal neurinomas and meningiomas. A clinical survey of 172 cases. Int Surg. 1971; 56:289-303.

6. Levy WJ, Latchaw J, Hahn JF. Spinal neurofibromas: a report of 66 cases and a comparison with meningiomas Neurosurgery. 1986; 18:331-334. Bangladesh Journal of Neurosurgery. 2019 January; 8(2):66.

https://doi.org/10.1227/00006123-198603000-00013

PMid:3084994

7. Salah S, Horcajada J, Perneczky A. Spinal neurinomas. A comprehensive clinical and statistical study on 47 cases. Neurochirurgia. 1975; 18:77-84.

https://doi.org/10.1055/s-0028-1090433

PMid: 1178096

8. Matti T. Seppala, M.D., Matti J. J. Haltia, M.D., Risto J. Sankila, et al. Long-term outcome after removal of spinal schwannoma: a clinicopathological study of 187 cases. J Neurosurg. 1995;83:621-626.

https://doi.org/10.3171/jns.1995.83.4.0621

PMid:7674010

9. Klekamp J, Samii M. Surgery of Spinal Tumours. Berlin: Springer;2007. 
10. Aghayev K, Vrionis F, Chamberlain MC. Adult intradural primary spinal cord tumours. J Natl Compr Canc Netw. 2011; 9: 434-447.

https://doi.org/10.6004/jncen.2011.0039

PMid:21464147

11. Albanese V, Platania N. Spinal intradural extramedullary tumours.Personal experience. J Neurosurg Sci. 2002;46: 18-24.

12. Riad H, Knafo S, Segnarbieux F, Lonjon N. Spinal meningiomas:surgical outcome and literature review. Neurochirurgie. 2013; 59: 30-34.

https://doi.org/10.1016/j.neuchi.2012.10.137

PMid:23395186

13. Gezen F, Kahraman S, Canakci Z. Review of 36 cases of spinal cord meningioma. Spine (Phila $\mathrm{Pa}$ 1976). 2000;25:727-731.

https://doi.org/10.1097/00007632-200003150-00013

PMid:10752106

14. CahillDW, Kumar R. Palliative subtotal vertebrectomy with anterior and posterior reconstruction via a single posterior approach. J Neurosurg. 1999; 90: 42-47.

https://doi.org/10.3171/spi.1999.90.1.0042

PMid:10413124

15. Cooper P, Errico T, Martin R. A systematic approach to spinal reconstruction after anterior decompression for neoplastic disease of the thoracic and lumbar spine. Neurosurgery. 1993;32:18(Medline).

https://doi.org/10.1097/00006123-199301000-00001

PMid:8421537

16. Gilbert RW, Kim JH, Posner JB. Epidural spinal cord compression from metastatic tumour : diagnosis and treatment. Ann Neurol. 1978; 3: 40-51 (Medline).

https://doi.org/10.1002/ana.410030107

PMid:655653

17. Han IH, Kuh SU, Chin DK, Jin BH, Cho YE. Surgical treatment of primary spinal tumours in the medullaris. J Kor Neurosurg Ass. 2008; 44(2): 72-77.

https://doi.org/10.3340/jkns.2008.44.2.72

PMid:19096696 PMCid:PMC2588334

18. Hufana V, Tan JSH, Tan KK. Microsurgical treatment for spinal tumours. Surg Med J. 2005; 46(2):74-77.

19. Klekamp J, Samii H. Surgical results for spinal metastases.

20. Acta Neurochir (Wien). 1998; 140: 957967(Medline).

21. Klimo P Jr, Kestle JR, Schmidt MH. Treatment of metastatic spinal epidural disease: a review of the literature. Neurosurg Focus. 2003;15(5): 1-9.

https://doi.org/10.3171/foc.2003.15.5.1

PMid: 15323458
22. Maranzano E, Latini P. Effectiveness of radiation therapywithout surgery in metastatic spinal cord compression:final results from a prospective trial. Int $\mathbf{J}$ Radiat Oncol BiolPhys. 1995; 32: 959-967(Medline).

https://doi.org/10.1016/0360-3016(95)00572-G

23. McCormick PC, Stein BM. Spinalcord tumours in adults. In: Youmans JR, editor. Neurological Surgery. Philadelphia. WB Saunders; 1998: 3102-3122.

24. Schwartz TH, McCormick PC. Intramedullary spinal cord tumours. Special issue. J Neurooncol. 2000; 47: 187-317.

https://doi.org/10.1023/A:1017289320326

25. Schwartz TH, McCormick PC. Intramedullary ependymomas: Clinical presentation, surgical treatment, strategies and prognosis. J Neurooncol.2000; 47:211-218.

https://doi.org/10.1023/A:1006414405305

PMid:11016737

26. Sciubba DM, Petteys RJ, GarcesAmbrossi GL, Noggle JC, McGirt MJ. Diagnosis and management of sacral tumours. J Neurosurg: Spine. 2009; 10(3): 244-256.

https://doi.org/10.3171/2008.12.SPINE08382

PMid:19320585

27. Solero CL, Formari M, Giombini S, Lasio G, Oliveri G, Cimino C, et al. Spinal meningeomas: review of 174 operated cases. Neurosurgery. 1989; 25: 153-160.

https://doi.org/10.1227/00006123-198908000-00001

https://doi.org/10.1097/00006123-198908000-00001

PMid:2671779

28. Sundaresan N, Digiacinto GV, Hughes JE. Treatment of neoplastic spinal cord compression: results of prospective study. Neurosurgery. 1991; 29: 645-650.

https://doi.org/10.1097/00006123-199111000-00001

https://doi.org/10.1227/00006123-199111000-00001

PMid:1961391

29. Sundaresan N, Steinberger AA, Moore F. Indications and results of combined anterior-posterior approaches for spine tumour surgery. J Neurosurg. 1996;85:438-446.

https://doi.org/10.3171/jns.1996.85.3.0438

PMid:8751630

30. Kenan Arnautovic, Aska Arnautovic. Extramedullary Intradural Spinal Tumours: A Review of Modern Diagnostic and Treatment Options and A Report of z Series. Bosnian Journal of Basic Medical Sciences. 2009; 9 (supplement 1): S40-S45.

https://doi.org/10.17305/bjbms.2009.2755

PMid:19912118 